\title{
Aikuiskasvatus ja yhteiskunnalliset kriisit
}

Osallistuin keväällä 1990 Israelissa Jerusalemissa järjestettyyn kansainväliseen seminaariin, jonka teemana oli aikuiskasvattajien rooli yhteiskunnallisissa kriiseissä.

Israel oli kieltämättä onnistunut järjestämispaikka juuri tämänaiheiselle seminaarille. Arabien ja juutalaisten välinen jännitys näkyi ja tuntui. Intifada jatkui. Omakohtaisesti vihan ilmapiiri tunkeutui luihin ja ytimiin Jerusalemin vanhassa kaupungissa tuhansien arabien virratessa rukoilemaan Kalliomoskeijaan tai Temppelivuorelle nuorten, vahvasti aseistettujen juutalaisnuorukaisten valvonnassa.

Seminaarin israelilaisten järjestäjien toimesta pyrittiin mahdollisimman objektiivisesti kuvaamaan vallitsevaa yhteiskunnallista tilannetta ja konfliktin ratkaisuvaihtoehtoja. Mm. meille kerrottiin kansalaisjärjestöjen ja aikuiskasvatusorganisaatioiden yrityksistä lisätä israelilaisten ja arabien välistä ymmärrystä ja kehittää yhdessä elämistä. Mahdollisuudet rauhanomaiseen ratkaisuun ovat olemassa, mikäli löytyy halua luopua jostain nyt tärkeänä pidetystä.

Seminaarissa oli osanottajia 12 maasta pääasiassa Saksan liittotasavallasta ja Israelista. Osanottajien enemmistön mukaisesti seminaarin aihepiireissä korostuivat juutalaisten kohtalot toisaalta natsi-Saksassa ja toisaalta itsenäisessä Israelissa. Seminaarissa käsiteltiin myös välittömästi toisen maailmansodan jälkeen Saksassa liittoutuneiden toimesta toteutettua poliittista kasvatusta. Muina aihepiireinä olivat $\mathrm{mm}$. poliittinen kasvatus ja propaganda aikuiskasvatuksessa, vallankumousten ja kansannousujen yhteydet aikuiskasvatukseen sekä siirtolaisten opetuksen ongelmat.

Seminaarin työskentelytapa oli tutustua alustusten pohjalta aikuiskasvatuksen rooliin erilaisissa kriiseissä.

Pohjois-Irlannin katolisten ja protestanttien konfliktiin liittyvästä aikuiskasvatusprojektista kuultiin eräs mieleenpainuvimmista alustuksista. Hankkeen tarkoituksena on saada pienryhmiin mukaan sekä katolisia että protestantteja. Ryhmät pyrkivät opiskelemaan konfliktin syitä ja et- simään ratkaisuja. Paha ja väärä, moraaliset, uskonnolliset ja taloudelliset mielipiteet törmäävät näissä ryhmissä. Erityisesti pelätään sitä, että ratkaisu tehdään meidän kustannuksellamme. Suomalaisesta näkökulmasta voi vain ihailla ja kunnioittaa ryhmien vetäjinä toimivia aikuiskasvattajia, jotka ilmeisesti henkensä kaupalla pyrkivät löytämään vaihtoehtoisia ratkaisuja väkivallalle.

Myös Itä-Euroopassa tapahtuneita pehmeitä vallankumouksia tarkasteltiin oppimisprosessin kautta. Analyyseissä korostettiin tiedon, tiedonvälityksen ja keskustelemisen merkitystä. Tämän muutosprosessin johdossa olivat yhteiskunnan intellektuellit. Omaehtoinen, vapaa sivistystyö nousi näissä maissa valtiollista propagandakoneistoa vastaan ja voitti sen. Tämä pehmeä vallankumous oli kansakunnille prosessi, jonka aikana liberaaliset ja demokraattiset aatteet kulkivat valtioiden rajojen yli sosialististen hallitusten niitä asevoimin estämättä. Erään seminaarissa esitetyn tulkinnan mukaan kyse oli pitkälti siitä, että tällä kertaa järki voitti väkivaltakoneiston. Eräs edellytys muutokselle oli yhteiskunnan kehittynyt koulujärjestelmä ja kansan sivistystaso.

Eurooppalaisiin kriiseihin ja muutosprosesseihin toi oman täydennyksensä seminaarin intialainen osanottaja, joka uskonnollisista perusteista lähtien kuvasi maansa yhteiskuntaa ja vallitsevaa köyhyyttä.

\section{Mitä opin}

Seminaarin eräänä johtavana ajatuksena oli demokraattisten arvojen edistäminen ja niiden suhde manipulaatioon, indoktrinaatioon ja poliittiseen propagandaan. Näistä käsitteistä yhteisen mielipiteen muodostaminen oli vaikeaa.

Kuitenkin demokratian toteuttamiseen liitettiin pluralismin, liberalismin ja vapauden periaatteet. Luonnollisesti näidenkin kolmen käsitteen määrittely oli ongelmallista.

Aidon poliittisen ja yhteiskunnallisen kasvatuksen päämääriksi voidaan seminaarin pohjalta todeta pyrkimys auttaa aikuista kasvamaan autonomiseksi ja suvereeniksi persoonallisuudeksi, 41 
joka on tietoinen oikeudestaan itsemääräämiseen ja kriittiseen ajatteluun.

Seminaarissa tulin entistä vakuuttuneemmaksi siitä, että yhteiskunnallisesti hiljaiset, tyytyväiset ajanjaksot saattavat johtaa kansalliseen lamautumiseen ja vähäiseen koulutukselliseen innovaati- oon, toisaalta materiaalisten arvojen korostaminen intellektuellisten kustannuksella lisää kulutusta, mutta ei luovuutta.

Yhteiskunnallista keskustelua maamme kehittämisen lähtökohdista ja vaihtoehdoista tulisi siis lisätä kaikessa opetuksessa sen eri tasoilla. 